\title{
Aboveground Production and C Flux in Three Chestnut High Forest Stands in Northern Portugal
}

\author{
M.S. Patrício, M.J. Fernandes and E. Pereira \\ Centro de Investigação de Montanha - CIMO \\ Bragança Polytechnic Institute, ESAB \\ Campus Sta. Apolónia, Apartado 1172 \\ 5301-855 Bragança \\ Portugal
}

\author{
D. Lopes \\ Universidade de Trás-os-Montes \\ e Alto Douro \\ Quinta dos Prados, Apartado 1013 \\ 5000-911 Vila Real \\ Portugal
}

Keywords: Castanea sativa Mill., litterfall biomass, net primary productivity

\begin{abstract}
Litterfall in three high forest chestnut stands in Marão, Padrela and Bornes (Northern Portugal), of 71, 64 and 53 years old, respectively, located on different soil types, was collected in the autumn of 2008 . Circular littertraps which cover a surface area of $1 \mathrm{~m}^{2}$ each were installed in these chestnut stands. The litterfall was separated into leaves, branches, fruits and burs. All litter fractions were dried to constant weight at $70^{\circ} \mathrm{C}$. The total amount of litter in the three stands was $4.2,4.6$ and $4.0 \mathrm{Mg}$ DM ha ${ }^{-1} \mathrm{y}^{-1}$ in Marão, Padrela and Bornes sites, respectively. Leaves are the main constituents of the total biomass return by litterfall contributing to $79.4 \%$ in Marão, $69.8 \%$ in Padrela and $78 \%$ in Bornes. The corresponding amounts of other litter fractions in these three locations were respectively: fruits $6.4 \%, 12.4 \%$ and $8.9 \%$; branches $6.4 \%, 4.0 \%$ and $4.7 \%$; burs $7.8 \%, 13.8 \%$ and $8.3 \%$. $C$ amount falling with litterfall was similar in the three stands, close to $2.3 \mathrm{Mg} \mathrm{C} \mathrm{ha}^{-1} \mathrm{y}^{-1}$. The aboveground net primary production ANPP was evaluated.
\end{abstract}

\section{INTRODUCTION}

Sweet chestnut (Castanea sativa Mill.) is an important species in the North of Portugal for fruit as well as for timber but the area of mature high forest stands is very limited, covering large areas with chestnut coppices.

Today, the role of the chestnut areas is not limited to production of fruit and timber but also other aspects such as landscape, environmental and ecological protection are very important. Consequently, its sustainable management is essential to maintain the health and vitality of the chestnut areas, therefore increasing the economical and social benefits for local inhabitants. Nevertheless, the last century has been characterized by a progressive decrease in areas covered by chestnut forests (Santa Regina, 2000) and Portugal was not an exception.

The site sustainability depends on the knowledge of the inputs and outputs of the system. Litter is an important reservoir of nutrients to maintain the site productivity and sustainability. In poor nutrient soils, the ecosystem productivity is highly influenced by the efficiency of nutrient cycling (Duvigneaud, 1984). However, growth and productivity of forest ecosystems depend mainly on the amount, nature and decomposition rate of litter (Kavvadias et al., 2001).

Species/soil interrelationships, climate, and stand age influence net primary production (NPP) of forests (Gower et al., 1997). Water and nutrient availability differ among different soils and influence both NPP and carbon allocation (Gower et al., 1995). Large differences in carbon allocation may affect the soil $\mathrm{C}$ cycle because the different plant tissues decompose at very different rates (Gower et al., 1997).

The first objective of this study is to assess the aboveground production on biomass and $\mathrm{C}$ flux falling on the soil. The second is to evaluate the aboveground net primary production (ANPP) for three chestnut mature high forest stands in northern Portugal. 


\section{MATERIALS AND METHODS}

\section{General Characteristics of the Sites}

In the study area, where the chestnut has its largest distribution, the mature high forest stands occupy an area of approximately 8 ha.

The study was conducted in the three mature chestnut stands located in Northern

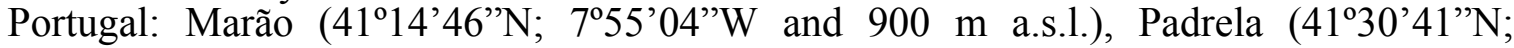
$7^{\circ} 37^{\prime} 15^{\prime \prime} \mathrm{W}$ and $850 \mathrm{~m}$ a.s.1.) and Bornes (41 ${ }^{\circ} 29^{\prime} 42^{\prime \prime} \mathrm{N} ; 6^{\circ} 55^{\prime} 12^{\prime \prime} \mathrm{W}$ and $800 \mathrm{~m}$ a.s.1.), with 71,64 and 53 years of age, respectively.

The mean annual rainfalls in Marão, Padrela and Bornes are, 2505, 1132 and 1009 $\mathrm{mm} \mathrm{y}^{-1}$, respectively, and the mean annual temperatures are $13.4,12.5$ and $11.9^{\circ} \mathrm{C}$, respectively.

Tree densities are 360, 470 and 1260 trees $^{-1}{ }^{-1}$ in Marão, Padrela and Bornes sites, respectively (Table 1).

Main soil types in the stands are Dystric Cambisols in Bornes, Umbric Regosols in Marão and Dystric Regosols in Padrela according to the World Reference Base for Soil (FAO, 1998). Table 2 presents the chemical properties of a type profile for each site.

\section{Methods Applied}

Aboveground litterfall was measured using 7 circular $1-\mathrm{m}^{2}$ littertraps that were randomly placed inside and outside of the sample tree plots (area $1000 \mathrm{~m}^{2}$ ) in each stand. Littertraps were deployed in September 2008 and litterfall was collected in October, November, December and January (2009).

The recovered litter was separated into leaves, branches, fruits and burs. All litter fractions were dried to constant weight at $70^{\circ} \mathrm{C}$.

The litter fractions were analysed for $\mathrm{N}, \mathrm{P}, \mathrm{K}, \mathrm{Ca}, \mathrm{Mg}, \mathrm{S}$ and $\mathrm{C}$, by applying specific analytical methods. $\mathrm{N}, \mathrm{P}$ and $\mathrm{K}$ were extracted by sulphuric digestion, $\mathrm{Ca}, \mathrm{Mg}$ and $\mathrm{S}$ by nitric-perchloric digestion (Walinga et al., 1989). The analytical determinations of $\mathrm{N}$ and $\mathrm{P}$ in the extract were obtained by atomic absorption spectrophotometry, the determination of $\mathrm{K}$ was performed by flame emission spectrophotometry, $\mathrm{Ca}$ and $\mathrm{Mg}$ through atomic absorption spectrophotometry and $\mathrm{S}$ via turbidimetry. $\mathrm{C}$ concentration was obtained by incineration at $1100^{\circ} \mathrm{C}$ with subsequent $\mathrm{CO}_{2}$ determination by the NonDispersive Infrared (NDIR) method.

Aboveground NPP (ANPP) was calculated according to Gower et al. (1997). According to these authors, the above NPP can be calculated as the sum of annual biomass (dry mass $(\mathrm{DM})$ ) increment $(\Delta \mathrm{B})$ of the components: trees and understory vegetation plus detritus production (losses), converted to $\mathrm{C}$ content. The losses are from biomass produced during the interval $\Delta \mathrm{t}$.

In each chestnut stand, a permanent plot with $1000 \mathrm{~m}^{2}$ had been established to evaluate the growth and yield of trees. The dimension of the plots and the large number of trees are sufficient to adequately characterize the forest. Diameter at breast height (DBH) $(1.30 \mathrm{~m})$ and total height were measured for all trees in each plot and period of time.

The data collected in the last 2 measures of these plots (2000 and 2008) were used to estimate the biomass on the same dates using allometric equations (Patrício et al., 2005). We used the estimated biomass to determine the annual biomass increment of the trees. The annual biomass increment was considered as the mean biomass produced between 2000-2008.

The understory vegetation was collected using $10(1 \times 1 \mathrm{~m})$ replicate plots in each stand randomly placed next to the littertraps. All aboveground understory vegetation that has been growing in $1 \times 1 \mathrm{~m}$ replication plots during a year was collected. Vegetation was separated into annual herbs, brackens, blackberry shrubs, seedlings and sprouts of chestnut. Samples were dried at $70^{\circ} \mathrm{C}$ and weighed to the nearest $0.10 \mathrm{~g}$.

The increment of the understory biomass was calculated as the sum of the dry biomass of all species that had been growing in each plot during a year. The ANPP was calculated as the sum of the dry biomass increment of stems and branches plus litterfall 
dry mass collected in the traps and understory biomass vegetation components. The biomass of the tree components, stem and branches, were multiplied by 0.48 and litterfall by 0.52 (Patrício, 2006) and the understory vegetation by 0.50 to estimate $\mathrm{C}$ content.

Table 1 summarizes the stand characteristics of the three stands.

\section{Statistical Methods}

An ANOVA was performed to compare the total amounts of litterfall among the three study sites. A Tukey test $(\alpha=0.05)$ was done for mean multiple comparisons. The same statistical analysis was used to compare the biomass mineral concentrations.

\section{RESULTS AND DISCUSSION} Table 3 .

Annual litterfall production and potential nutrient return to the soil are indicated in

Total litterfall was similar in the three old chestnut stands $(p>0.05)$. Comparing these results with Patricio et al. (2009) relatively small quantities of litterfall were observed here. This discrepancy can be due to the different methodologies used to collect the litterfall (quadrate method and littertraps). Further research will be necessary to compare and verify both methodologies in the same period of litterfall collecting.

As in the case of most forest ecosystems, the leaves comprised the most important fraction of litter biomass ranged from 3.1 to $3.3 \mathrm{Mg} \mathrm{ha}^{-1} \mathrm{y}^{-1}$ (representing 69.8-79.4\% of the total litterfall). They sequester the largest amount of $\mathrm{C}$ too. Branches fall contribution was smaller than leaves and only represented $4-6 \%$ of the total litterfall. Fruits and burs represented $6.4-12.4 \%$ and $7.8-13.9 \%$, respectively of the annual total litterfall. These results are consistent with Santa Regina (2000) for the leaves component but not for the others because, in our case, the contribution of burs and fruits is higher than branches. However, densities and ages of the three stands are very different.

The values of total litterfall are approximate to the values of $3.9 \mathrm{Mg} \mathrm{ha}^{-1} \mathrm{y}^{-1}$ reported by Pires et al. (1994) for chestnut groves and 4.9 $\mathrm{Mg} \mathrm{ha}^{-1} \mathrm{y}^{-1}$ referred to by Santa Regina (2000).

The potential contribution of nutrients to the soil is presented in Table 3. From these elements we highlight $\mathrm{N}$ and $\mathrm{Ca}$ as the major contribution to the ecosystem. However, the leaf litter fraction was the main vector of the potential return of all bioelements to the soil.

Bornes presents the lowest input amount of $\mathrm{N}$ litterfall in relations to the other sites due to the scarcity of this element in this soil (Table 2).

The ANPP of the three stands is presented in Table 4. The results obtained showed that ANPP for the three chestnut stands range from 3.7 to $5.2 \mathrm{Mg} \mathrm{C}^{-1} \mathrm{y}^{-1}$.

As can be observed, the ANPP is lower in Marão, the oldest stand. This situation could be due to the lower density of trees. However, it is a fact that in mature forests, aboveground biomass production declines with the age of the stands and affects NPP which in turn affects $\mathrm{C}$ and nutrient cycling characteristics of forests. Nevertheless, the mechanism(s) responsible for the decline are not well understood (Gower et al., 1996).

Litterfall production is a major component of ANPP for the oldest chestnut stand (Marão) followed by tree organs (stem plus branches) contribution. In Bornes, the youngest stand, the $\mathrm{C}$ sequestered in the stems is similar to the $\mathrm{C}$ restored to the soil by the litterfall. The litter component is practically the major pathway for carbon input into the soil in the three stands.

\section{CONCLUSIONS}

This study shows, for our conditions, that the aboveground biomass productions of the mature stands of chestnut high forest range from 7-10 Mg DM ha ${ }^{-1} \mathrm{y}^{-1}$. They produced about 4-4.5 Mg DM ha ${ }^{-1} \mathrm{y}^{-1}$ of total litterfall.

As in the case of most forest ecosystems, the leaves comprise the most important fraction of litter biomass representing approximately $3 \mathrm{Mg} \mathrm{ha}^{-1} \mathrm{y}^{-1}(70-79 \%$ of the total litterfall). They also sequester the largest amount of $\mathrm{C}\left(1.6-1.8 \mathrm{Mg} \mathrm{ha}^{-1} \mathrm{y}^{-1}\right)$ and they are 
the main vector of the potential return of all bio-elements to the soil. $\mathrm{N}$ and $\mathrm{Ca}$ are their major nutrient contributions to the ecosystem.

Litterfall is a major component of ANPP for chestnut high forest old stands and is practically the major pathway for carbon input into the soil.

The ANPP for the three chestnut stands ranges from 3.7 to $5.2 \mathrm{Mg} \mathrm{C} \mathrm{ha}^{-1} \mathrm{y}^{-1}$. The lowest value was observed in the oldest stand.

\section{ACKNOWLEDGEMENTS}

This study was supported by FCT project number PDTC/AGR-CFL/68186/2006.

\section{Literature Cited}

Duvigneaud, P. 1984. L'écosystème forêt. Ecole nationale de génie rural, des eaux et des forêts, Nancy, 159p.

FAO. 1998. World reference base for soil resources. World Soil Resources Reports, Rome, 84, 88p.

Gower, S.T., Isebrands, J.G. and Sheriff, D.W. 1995. Carbon allocation and accumulation in conifers. p.217-254. In: W. Smith and T.M. Hinckley (eds.), Resource Physiology of Conifers, Academic, San Diego, California.

Gower, S.T., McMurtrie, R.E. and Murty, D. 1996. Aboveground net primary production decline with stand age: Potential causes. Trends Ecol. Evol. 11:378-382.

Gower, S.T., Vogel, J.G., Norman, J.M., Kucharik, C.J. and Steele, S.J. 1997. Carbon distribution and aboveground net primary production in aspen, jack pine, and black spruce stands in Saskatchewan and Manitoba, Canada. J. Geophys. Res. 102:29,029$29,041$.

Kavvadias, V.A., Alifragis, D., Alexandros, T., Brofas, G. and Stamatelos, G. 2001. Litterfall, litter accumulation and litter decomposition rates in four forest ecosystems in northern Greece. Forest Ecol. Man. 144:113-127.

Patrício, M.S., Monteiro, M.L. and Tomé, M. 2005. Biomass equations for Castanea sativa high forest in the northwest of Portugal. Acta Hort. 693:727-732.

Patrício, M.S. 2006. Análise da potencialidade produtiva do castanheiro em Portugal. Tese de Doutoramento. Universidade Técnica de Lisboa, Instituto Superior de Agronomia, 232p.

Patrício, M.S., Pereira, E., Nunes, L.F. and Monteiro, M.L. 2009. Carbon and nutrient inputs by litterfall into three chestnut high forest stands in Northern Portugal. Acta Hort. 815:69-74.

Pires, A.L., Portela, E. and Martins, A.A. 1994. Nutrient cycling in chestnut groves in the Tras-os-Montes region. p.9-22. In: Romane (ed.), Biological criteria for sustainable development in natural degenerate forests of Mediterranean Europe. Montpellier.

Santa Regina, I.S. 2000. Organic matter distribution and nutrient fluxes within a sweet chestnut (Castanea sativa Mill.) stand of the Sierra de Gata, Spain. Ann. For. Sci. 57:691-700.

Walinga, I., van Vark, W., Houba, V.J.G. and van der Lee, J.J. 1986. Soil and plant analysis, a series of syllabi. Part 7 Plant analysis procedures. Wageningen University, Department of Soil Science and Plant Nutrition. 


\section{Tables}

Table 1. General characteristics of the studied chestnut stands (Northern Portugal).

\begin{tabular}{lccc}
\hline Chestnut stands & Marão & Padrela & Bornes \\
\hline Altitude (m a.s.l.) & 900 & 850 & 800 \\
Slope $\left({ }^{\circ}\right)$ & $5-10$ & $25-30$ & $15-20$ \\
Stand age (y, in 2008) & 71 & 64 & 53 \\
Mean annual temperature $\left({ }^{\circ} \mathrm{C}\right)$ & 13.4 & 12.5 & 11.9 \\
Mean annual precipitation $\left(\mathrm{mm} \mathrm{y}^{-1}\right)$ & 2505 & 1132 & 1009 \\
Density (tree ha $\left.^{-1}\right)$ & 360 & 470 & 1260 \\
Mean DBH $(\mathrm{cm})$ & 40.5 & 34.0 & 26.8 \\
Mean height $(\mathrm{m})$ & 29.9 & 21.3 & 23.8 \\
\hline
\end{tabular}

Table 2. Chemical properties of a type profile by site.

\begin{tabular}{|c|c|c|c|c|c|c|c|c|c|}
\hline \multirow{2}{*}{ Stands } & \multirow{2}{*}{$\begin{array}{l}\text { Depth } \\
\text { (cm) }\end{array}$} & \multirow{2}{*}{$\begin{array}{c}\mathrm{pH} \\
\left(\mathrm{H}_{2} \mathrm{O}\right)\end{array}$} & \multirow{2}{*}{\multicolumn{2}{|c|}{$\frac{C \quad N}{\left(g_{k g}^{-1}\right)}$}} & \multirow{2}{*}{$\begin{array}{c}\mathrm{P} \\
\left(\mathrm{mg} \mathrm{kg}^{-1}\right)\end{array}$} & $\mathrm{Ca}$ & $\mathrm{Mg}$ & $\mathrm{K}$ & $\mathrm{Na}$ \\
\hline & & & & & & \multicolumn{4}{|c|}{$\left(\mathrm{cmolc} \mathrm{kg}^{-1}\right)$} \\
\hline \multirow{3}{*}{ Marão } & $0-25$ & 4.6 & 114 & 6.8 & 3.9 & 0.06 & 0.24 & 0.23 & 0.07 \\
\hline & $25-65$ & 4.9 & 52 & 5.1 & 4.8 & 0.05 & 0.11 & 0.11 & 0.08 \\
\hline & $65-150$ & 5.1 & 82 & 4.2 & 1.8 & 0.03 & 0.05 & 0.12 & 0.10 \\
\hline \multirow{3}{*}{ Padrela } & $0-8$ & 5.2 & 72 & 4.4 & 13 & 1.1 & 0.50 & 0.66 & 0.08 \\
\hline & $8-65$ & 4.9 & 66 & 3.0 & 3.1 & 0.30 & 0.14 & 0.30 & 0.06 \\
\hline & $65-105$ & 5.1 & 18 & 2.0 & 2.2 & 0.24 & 0.03 & 0.09 & 0.03 \\
\hline \multirow{3}{*}{ Bornes } & $0-35$ & 5.5 & 35 & 1.8 & 0.87 & 1.1 & 0.91 & 0.22 & 0.08 \\
\hline & $35-60$ & 5.3 & 27 & 1.3 & 0.43 & 0.53 & 0.29 & 0.10 & 0.08 \\
\hline & $60-100$ & 5.4 & 26 & 0.40 & 0.43 & 0.78 & 0.56 & 0.05 & 0.04 \\
\hline
\end{tabular}


Table 3. Average annual litter production and bio-element amounts of litterfall components in three high forest mature chestnut stands (Northern Portugal).

\begin{tabular}{|c|c|c|c|c|c|c|c|c|c|c|}
\hline \multirow{2}{*}{ Stands } & \multirow{2}{*}{ Litter fraction } & \multicolumn{2}{|c|}{ Litter production } & $\mathrm{N}$ & $\mathrm{P}$ & K & $\mathrm{Ca}$ & $\mathrm{Mg}$ & $\mathrm{S}$ & $\mathrm{C}$ \\
\hline & & \multicolumn{2}{|c|}{$\left(\mathrm{Mg} \mathrm{DM} \mathrm{ha}^{-1} \mathrm{y}^{-1}\right)(\%)$} & \multicolumn{7}{|c|}{$\left(\mathrm{kg} \mathrm{ha}^{-1} \mathrm{yr}^{-1}\right)$} \\
\hline \multirow{5}{*}{ Marão } & Leaves & $\begin{array}{c}3.33 \\
(0.11)\end{array}$ & 79.4 & $\begin{array}{c}49.7 \\
(1.62)\end{array}$ & $\begin{array}{c}3.42 \\
(0.11)\end{array}$ & $\begin{array}{c}5.81 \\
(0.19)\end{array}$ & $\begin{array}{c}14.6 \\
(0.48)\end{array}$ & $\begin{array}{c}8.38 \\
(0.27)\end{array}$ & $\begin{array}{c}1.50 \\
(0.05)\end{array}$ & $\begin{array}{r}1819 \\
(59.5)\end{array}$ \\
\hline & Branches & $\begin{array}{c}0.27 \\
(0.21)\end{array}$ & 6.38 & $\begin{array}{c}1.63 \\
(1.28)\end{array}$ & $\begin{array}{c}0.13 \\
(0.10)\end{array}$ & $\begin{array}{c}0.30 \\
(0.23)\end{array}$ & $\begin{array}{c}3.08 \\
(2.40)\end{array}$ & $\begin{array}{c}0.71 \\
(0.55)\end{array}$ & $\begin{array}{c}0.12 \\
(0.09)\end{array}$ & $\begin{array}{c}143 \\
(111)\end{array}$ \\
\hline & Burs & $\begin{array}{c}0.33 \\
(0.11)\end{array}$ & 7.79 & $\begin{array}{c}2.93 \\
(1.03)\end{array}$ & $\begin{array}{c}0.26 \\
(0.09)\end{array}$ & $\begin{array}{c}0.64 \\
(0.22)\end{array}$ & $\begin{array}{c}0.64 \\
(0.22)\end{array}$ & $\begin{array}{c}0.63 \\
(0.22)\end{array}$ & $\begin{array}{c}0.05 \\
(0.02)\end{array}$ & $\begin{array}{c}172 \\
(60.2)\end{array}$ \\
\hline & Fruits & $\begin{array}{c}0.27 \\
(0.09)\end{array}$ & 6.41 & $\begin{array}{c}3.06 \\
(1.08)\end{array}$ & $\begin{array}{c}0.29 \\
(0.10)\end{array}$ & $\begin{array}{c}1.14 \\
(0.40)\end{array}$ & $\begin{array}{l}1.25 \\
(0.44)\end{array}$ & $\begin{array}{c}0.99 \\
(0.35)\end{array}$ & $\begin{array}{c}0.11 \\
(0.04)\end{array}$ & $\begin{array}{c}143 \\
(50.5) \\
\end{array}$ \\
\hline & Total & $\begin{array}{l}4.19 \mathrm{a} \\
(0.32) \\
\end{array}$ & 100 & $\begin{array}{l}57.3 \mathrm{a} \\
(2.89) \\
\end{array}$ & $\begin{array}{l}4.10 \mathrm{~b} \\
(0.23) \\
\end{array}$ & $\begin{array}{l}7.89 \mathrm{~b} \\
(0.66) \\
\end{array}$ & $\begin{array}{l}19.6 \mathrm{~b} \\
(2.81) \\
\end{array}$ & $\begin{array}{l}10.7 \mathrm{c} \\
(0.89) \\
\end{array}$ & $\begin{array}{l}1.77 \mathrm{~b} \\
(0.13) \\
\end{array}$ & $\begin{array}{r}2277 \mathrm{a} \\
(173) \\
\end{array}$ \\
\hline \multirow{5}{*}{ Padrela } & Leaves & $\begin{array}{c}3.21 \\
(0.35)\end{array}$ & 69.8 & $\begin{array}{c}46.4 \\
(5.07)\end{array}$ & $\begin{array}{c}3.73 \\
(0.41)\end{array}$ & $\begin{array}{c}14.9 \\
(1.63)\end{array}$ & $\begin{array}{c}22.4 \\
(2.45)\end{array}$ & $\begin{array}{c}10.6 \\
(1.16)\end{array}$ & $\begin{array}{c}2.77 \\
(0.30)\end{array}$ & $\begin{array}{l}1576 \\
(172)\end{array}$ \\
\hline & Branches & $\begin{array}{c}0.18 \\
(0.16)\end{array}$ & 3.99 & $\begin{array}{c}1.54 \\
(1.42)\end{array}$ & $\begin{array}{c}0.09 \\
(0.08)\end{array}$ & $\begin{array}{c}0.48 \\
(0.44)\end{array}$ & $\begin{array}{c}1.43 \\
(1.31)\end{array}$ & $\begin{array}{c}0.31 \\
(0.28)\end{array}$ & $\begin{array}{c}0.16 \\
(0.14)\end{array}$ & $\begin{array}{l}92.8 \\
(85.5)\end{array}$ \\
\hline & Burs & $\begin{array}{c}0.64 \\
(0.37)\end{array}$ & 13.9 & $\begin{array}{c}8.46 \\
(4.98)\end{array}$ & $\begin{array}{c}0.76 \\
(0.45)\end{array}$ & $\begin{array}{l}3.60 \\
(2.12)\end{array}$ & $\begin{array}{c}3.69 \\
(2.17)\end{array}$ & $\begin{array}{c}1.30 \\
(0.76)\end{array}$ & $\begin{array}{c}0.36 \\
(0.21)\end{array}$ & $\begin{array}{c}312 \\
(184)\end{array}$ \\
\hline & Fruits & $\begin{array}{c}0.57 \\
(0.32) \\
\end{array}$ & 12.4 & $\begin{array}{c}7.43 \\
(4.29) \\
\end{array}$ & $\begin{array}{c}0.58 \\
(0.34) \\
\end{array}$ & $\begin{array}{c}2.90 \\
(1.68)\end{array}$ & $\begin{array}{c}1.95 \\
(1.13)\end{array}$ & $\begin{array}{c}1.23 \\
(0.70)\end{array}$ & $\begin{array}{c}0.29 \\
(0.17)\end{array}$ & $\begin{array}{c}282 \\
(163) \\
\end{array}$ \\
\hline & Total & $\begin{array}{l}4.60 \mathrm{a} \\
(0.69) \\
\end{array}$ & 100 & $\begin{array}{l}63.8 \mathrm{a} \\
(9.38) \\
\end{array}$ & $\begin{array}{l}5.16 \mathrm{a} \\
(0.79) \\
\end{array}$ & $\begin{array}{l}21.9 \mathrm{a} \\
(3.68) \\
\end{array}$ & $\begin{array}{l}29.5 \mathrm{a} \\
(3.79)\end{array}$ & $\begin{array}{l}13.4 \mathrm{~b} \\
(1.67) \\
\end{array}$ & $\begin{array}{l}3.58 \mathrm{a} \\
(0.43) \\
\end{array}$ & $\begin{array}{r}2262 \mathrm{a} \\
(339) \\
\end{array}$ \\
\hline \multirow{5}{*}{ Bornes } & Leaves & $\begin{array}{c}3.09 \\
(0.40)\end{array}$ & 78.0 & $\begin{array}{c}31.6 \\
(4.07)\end{array}$ & $\begin{array}{c}3.41 \\
(0.44)\end{array}$ & $\begin{array}{c}14.8 \\
(1.90)\end{array}$ & $\begin{array}{c}28.0 \\
(3.61)\end{array}$ & $\begin{array}{c}16.0 \\
(2.06)\end{array}$ & $\begin{array}{c}1.22 \\
(0.16)\end{array}$ & $\begin{array}{l}1654 \\
(213)\end{array}$ \\
\hline & Branches & $\begin{array}{c}0.19 \\
(0.17)\end{array}$ & 4.74 & $\begin{array}{c}1.03 \\
(0.98)\end{array}$ & $\begin{array}{c}0.07 \\
(0.06)\end{array}$ & $\begin{array}{c}0.20 \\
(0.18)\end{array}$ & $\begin{array}{c}1.47 \\
(1.41)\end{array}$ & $\begin{array}{c}0.34 \\
(0.33)\end{array}$ & $\begin{array}{c}0.02 \\
(0.01)\end{array}$ & $\begin{array}{c}95.7 \\
(91.8)\end{array}$ \\
\hline & Burs & $\begin{array}{c}0.33 \\
(0.13)\end{array}$ & 8.28 & $\begin{array}{c}2.31 \\
(0.91)\end{array}$ & $\begin{array}{c}0.22 \\
(0.09)\end{array}$ & $\begin{array}{c}1.03 \\
(0.41)\end{array}$ & $\begin{array}{c}1.62 \\
(0.64)\end{array}$ & $\begin{array}{c}1.24 \\
(0.49)\end{array}$ & $\begin{array}{c}0.07 \\
(0.03)\end{array}$ & $\begin{array}{c}167 \\
(66.4)\end{array}$ \\
\hline & Fruits & $\begin{array}{c}0.35 \\
(0.22) \\
\end{array}$ & 8.94 & $\begin{array}{c}3.79 \\
(2.39) \\
\end{array}$ & $\begin{array}{c}0.38 \\
(0.24) \\
\end{array}$ & $\begin{array}{c}2.15 \\
(1.36) \\
\end{array}$ & $\begin{array}{c}0.49 \\
(0.31) \\
\end{array}$ & $\begin{array}{c}0.70 \\
(0.44) \\
\end{array}$ & $\begin{array}{c}0.11 \\
(0.07) \\
\end{array}$ & $\begin{array}{c}176 \\
(111) \\
\end{array}$ \\
\hline & Total & $\begin{array}{l}3.96 a \\
(0.52)\end{array}$ & 100 & $\begin{array}{l}38.7 b \\
(5.34)\end{array}$ & $\begin{array}{l}4.09 b \\
(0.57)\end{array}$ & $\begin{array}{l}18.2 \mathrm{a} \\
(2.76)\end{array}$ & $\begin{array}{l}31.6 \mathrm{a} \\
(3.73)\end{array}$ & $\begin{array}{c}18.3 \mathrm{a} \\
(2.23)\end{array}$ & $\begin{array}{c}1.43 b \\
(0.19)\end{array}$ & $\begin{array}{c}2093 a \\
(271)\end{array}$ \\
\hline
\end{tabular}

* Letters indicate significant differences at $\mathrm{p} \leq 0.05$ among means (Tukey test) for total litter. Values in parentheses are standard deviations. 
Table 4. Aboveground Net Primary Production (ANPP, in $\mathrm{Mg} \mathrm{C} \mathrm{ha}^{-1} \mathrm{y}^{-1}$ ) by component for chestnut high forest stands (Northern, Portugal).

\begin{tabular}{|c|c|c|c|c|c|c|}
\hline \multirow[t]{2}{*}{ Stands } & \multirow[t]{2}{*}{$\begin{array}{l}\text { Tree density } \\
\left(\text { trees ha }^{-1}\right)\end{array}$} & \multirow[t]{2}{*}{$\begin{array}{l}\text { Stand } \\
\text { age }(y)\end{array}$} & \multicolumn{2}{|c|}{$\begin{array}{l}\text { Aboveground production } \\
(\Delta \mathrm{B})\left(\mathrm{Mg} \mathrm{DM} \mathrm{ha}^{-1} \mathrm{y}^{-1}\right)\end{array}$} & \multicolumn{2}{|c|}{$\begin{array}{l}\text { C flux to soil } \\
\left(\mathrm{MgC} \mathrm{ha}^{-1} \mathrm{y}^{-1}\right)\end{array}$} \\
\hline & & & Stem & 1.57 & Stem & 0.76 \\
\hline & & & Branches & 0.68 & Branches & 0.33 \\
\hline \multirow[t]{5}{*}{ Marão } & 360 & 71 & Understory & 0.86 & Understory & 0.43 \\
\hline & & & Litterfall & 4.19 & Litterfall & 2.18 \\
\hline & & & Total & 7.30 & ANPP & 3.70 \\
\hline & & & Stem & 4.38 & Stem & 2.10 \\
\hline & & & Branches & 1.12 & Branches & 0.54 \\
\hline \multirow[t]{5}{*}{ Padrela } & 470 & 64 & Understory & 0.34 & Understory & 0.17 \\
\hline & & & Litterfall & 4.60 & Litterfall & 2.39 \\
\hline & & & Total & 10.4 & ANPP & 5.20 \\
\hline & & & Stem & 4.25 & Stem & 2.04 \\
\hline & & & Branches & 1.05 & Branches & 0.50 \\
\hline \multirow[t]{3}{*}{ Bornes } & 1260 & 53 & Understory & 0.51 & Understory & 0.25 \\
\hline & & & Litterfall & 3.96 & Litterfall & 2.06 \\
\hline & & & Total & 9.77 & ANPP & 4.85 \\
\hline
\end{tabular}


